\title{
Development of Evaluation Metrics for Learners in Unplugged Activity
}

Woochun Jun*

Seoul National University of Education, Department of Computer Education, 06639, Korea

\begin{tabular}{l} 
A R T I C L E I N F O \\
\hline Article history: \\
Received: 14 July, 2019 \\
Accepted: 04 November, 2019 \\
Online: 05 December, 2019 \\
\hline Keywords: \\
Unplugged Activity \\
Unplugged Computing \\
Evaluation Metrics
\end{tabular}

\begin{abstract}
A B S T R A C T
As well as physical computing, unplugged activity is important in ICT (Information and Communication Technology) education, that uses information and communications technology to support, enhance, and optimize the delivery of information, and software education. In order to achieve educational objectives in unplugged activity, evaluation metrics of learners are necessary. However, there is little work on evaluation metrics in unplugged activity. In this paper, evaluation metrics of learners are proposed and developed using based on the general design principles and opinions of experts.
\end{abstract}

\section{Introduction}

This paper is an extension of work originally presented in ICTC2018[1].

Unplugged activity is a teaching method that literally learns about a computer without using a computer. In the origin, Professor Tim Bell of New Zealand suggested a new way of teaching students to learn the principles of computer science by learning the principles of computer operation and creative ideas that invented and developed computers through specific manipulation activities. Through the unplugged method, play learning materials in the form of specific manipulations were developed and applied to understand the principles of operation of algorithms and computers, such as expression, alignment, search, algorithm, routing, and deadlock of data without using the computer.

Unplugged learning is a new method of education for elementary and middle school computer education, so students can learn the principles of computer science easily and interestingly. Unplugged learning was initially a teaching method for elementary school students, but it can be easily used and applied to anyone who wants to learn the principles of computer science. Learning in the form of play related to specific experiences and real life has led to a change in the concept of computer science as an easier and more interesting subject. And it gave teachers a new direction in

*Corresponding Author: Woochun Jun, Seocho Dong, Seocho Gu, Seoul, Korea, wocjun@snue.ac.kr computer education to effectively teach logical computer science subjects without the need for computer and programming.

Unplugged activity has a big advantage. That is, it is to let students not to feel busy, feel fun and good. It also emphasizes cooperative thinking rather than competition from individuals, and uses computers to help people think in abundance. Unplugged activity can be said to be a new computer education created between ideas and activities for learners, and it has given teachers a new direction in computer education in that they can effectively teach logical computer science subjects without the need for computer and programming learning [2,3].

For the successful fulfillment of unplugged activity in ICT education, it is necessary to establish certain and secure evaluation standards or metrics for learners. That is, according to proper evaluation metrics, learners must be evaluated and education contents or teaching-learning method can be updated or modified depending on result of evaluation metrics.

However, in the literature, there is little research work on evaluation of learners in unplugged activity. The purpose of this paper is to develop evaluation metrics of learners in unplugged activity. For this purpose, in this work, overall categories are proposed and detailed evaluation metrics items are proposed depending on each category.

The rest of this paper is organized as follows. In Chapter 2, related works for unplugged activity is introduced. In Chapter3, evaluation metrics of learners are proposed. Finally, in Chapter 4, conclusions and further research issues are discussed. 


\section{Related Works}

\subsection{Principles of Unplugged Activity}

In the literature [4], there are 10 principles of unplugged activity. That is, 10 class activity design principles are suggested. Those principles are also main characteristics of unplugged activity. The followings are those principles.

\section{- No Computers Required}

The first principle implies that a computer is not used at all. It means that the main objective of unplugged activity is not to use computers while students are learning the principles and concepts of computer science.

\section{- Real Computer Science}

Unplugged activity can have students to know basic principles of computer science such as database, software engineering, computer architecture, computer graphics, communication network, operating systems, and programming languages through a variety of unplugged activities. That is, the purpose of unplugged activity is to let students understand the various concepts of computer science. It means that unplugged activity must include the main principles of computer science in their activities.

\section{- $\quad$ Learning by doing}

"Learning by doing" is accompanied by the emphasis of progressive education. It provides solutions based on the constructivism that students can learn new concepts by participating in active activities voluntarily with a purpose. That is, students can learn the concepts of computer science through discovery learning on their own. That is, rather than providing what learners need to know from the beginning, such as the discovery learning principle presented by Brunner, the learning can proceed in a situation that requires the learner to organize the final form or content on his or her own. In other words, the logic is that students can understand their learning more deeply by participating in the discovery process of knowledge. Therefore, it does not conform to the basic concepts of unplugged activities to present and understand concepts, principles and ideas immediately.

\section{- Fun}

Unplugged activity should keep the rules and principles by learning the concepts of computer science through play and activity, gain fun through play, and make learners feel a sense of achievement in your activities. This is because if students are not given enough fun in the course of "Learning by doing," they can turn into activities that the teacher understands and forces them to understand rather than acquire them. Therefore, teachers present some rules along with basic data, and students solve tasks according to the rules presented by the teachers. The caveat in unplugged activities should be that the activities give students challenges and competitive psychology, as well as fully reflecting the interesting points in the process of problem solving. The activities should also be organized so that students can be fully satisfied with the sense of achievement they achieve in the process.

- No special equipment

www.astesj.com
The materials available for use in unplugged activities can be various objects used in our lives. That is, we do not use computers, and we use things that are readily available around us to organize activities that include the concepts of computer science. For instance, various materials can be used, such as cards, threads, chalk, cups, balls, pencils, and colored paper.

- Variation encouraged

Unplugged activity recommends that computer scientists from all over the world participate together through the Creative Commons License (CCL). It also respects open thinking so that changes, adaptations and extensions can be made to previously developed activities.

\section{- $\quad$ For Everyone}

Unplugged activity can be applied to any age group. If you are a beginner who first comes across the principles of computer science, you can use them extensively, from elementary school students to the elderly, regardless of age. It can also be used in various ways, not dependent on a particular country, culture or society.

\section{- Co-operative}

One of unplugged activity's main goals is cooperation. In other words, rather than solving a problem on the learner's own, he or she solves the problem through various collaborative work with his colleagues, and discovers the principles of computer science contained in it. That is, it emphasizes collaborative learning, which is the main philosophy of the theory of constructivism of learning. It is suitable for team activities rather than individuals, and is applicable in competitive situations.

\section{- Stand-alone activities}

The main objective of unplugged activities is to acquire the concepts of computer science embedded in the content of the activities, while carrying out activities that include the basic concepts or principles of computer science. Therefore, individual activity should not be dependent each other and can present a single computer principle in one activity. In other words, if multiple concepts or principles are included in an activity, it is difficult to exclude the possibility of a misconception.

\section{- Resilient}

Since unplugged activity is focused on activities that can learn the concepts or principles of computer science and also does not focus on understanding or memorization, it is difficult to present the principles or all very difficult steps precisely. Therefore, even if there is the possibility of small mistakes or misconceptions, it should be able to demonstrate the flexibility to implement them, unless they are a major obstacle to understanding the principles of computer science.

\subsection{Literature Review}

In [5], unplugged activities for information protection education applicable to primary and secondary schools are proposed. Unplugged activities developed in this study were designed using Lickona's integrated morality model and unplugged activity design pattern, and developed after expert review and pilot testing for elementary school students. The developed activities were applied to 21 middle school students and their usefulness was assessed. 
In [1], an evaluation standard of unplugged activity is proposed. The following table 1 shows the whole standard.

Table 1: Evaluation Standard

\begin{tabular}{|c|c|c|}
\hline Number & Standards & Description \\
\hline 1 & Computer & \begin{tabular}{lr}
\multicolumn{1}{c}{ Is any } & $\begin{array}{l}\text { computer } \\
\text { (including }\end{array}$ \\
notebook, \\
tablet PC, & or other \\
electronic & devices) \\
necessary? &
\end{tabular} \\
\hline 2 & Fun & $\begin{array}{l}\text { Does the activity give } \\
\text { fun to students? }\end{array}$ \\
\hline 3 & $\begin{array}{c}\text { Computer } \\
\text { Science Principle }\end{array}$ & $\begin{array}{l}\text { Does the activity } \\
\text { deliver any idea or } \\
\text { principle of computer } \\
\text { science theory? }\end{array}$ \\
\hline 4 & $\begin{array}{c}\text { Student } \\
\text { Participation }\end{array}$ & $\begin{array}{l}\quad \text { Does the activity } \\
\text { require active } \\
\text { participation of all } \\
\text { students? }\end{array}$ \\
\hline 5 & $\begin{array}{l}\text { Independent } \\
\text { Activity }\end{array}$ & $\begin{array}{l}\text { Does the activity } \\
\text { represent any } \\
\text { independent computer } \\
\text { science theory? }\end{array}$ \\
\hline 6 & $\begin{array}{l}\text { Learning by } \\
\text { Doing }\end{array}$ & $\begin{array}{l}\text { Does student learn by } \\
\text { doing? }\end{array}$ \\
\hline 7 & For everyone & $\begin{array}{l}\text { Can everyone } \\
\text { participate the activity? }\end{array}$ \\
\hline 8 & Background & $\begin{array}{l}\text { Does the activity } \\
\text { require any academic } \\
\text { background or } \\
\text { preliminary course? }\end{array}$ \\
\hline 9 & Safety & Is the activity is safe? \\
\hline 10 & Report & $\begin{array}{l}\text { Does the activity let } \\
\text { student submit activity } \\
\text { report? }\end{array}$ \\
\hline
\end{tabular}

\section{Development of Evaluation Metrics for Learners}

In this chapter, evaluation metrics for learners in unplugged activity are proposed. The proposed metric is developed based on the previous research works and experts from ICT education such as professors and teachers.

\subsection{Design Principles}

The proposed evaluation metrics are developed as following principles. First, they are based on 10 design principles of unplugged activity in previous chapter. It means that the metrics are in accordance with 10 design principles. Second, the proposed metrics are developed to test students' participation and interest in unplugged activity. Third, metrics are developed to test how much learners understand the overall idea or principle in computer science theory.

\subsection{Evaluation Metrics}

The following table 2 shows the overall evaluation metrics of unplugged activity.

Table 2: Evaluation Metrics

\begin{tabular}{|c|c|c|}
\hline Number & Metrics & Description \\
\hline 1 & Understanding & $\begin{array}{l}\text { Do learners understand } \\
\text { the whole idea or } \\
\text { principle of computer } \\
\text { science theory? }\end{array}$ \\
\hline 2 & Fun & $\begin{array}{l}\text { Do learners have fun or } \\
\text { feel fun during } \\
\text { unplugged activity? }\end{array}$ \\
\hline 3 & Participation & $\begin{array}{l}\text { Do learners participate in } \\
\text { activity actively or } \\
\text { positively? }\end{array}$ \\
\hline 4 & Interest & $\begin{array}{l}\text { Do learners have } \\
\text { interests on unplugged } \\
\text { activity? }\end{array}$ \\
\hline 5 & Safety & $\begin{array}{l}\text { Do learners feel safe } \\
\text { during unplugged } \\
\text { activity? }\end{array}$ \\
\hline 6 & Cooperation & $\begin{array}{l}\text { Are learners engaged } \\
\text { well in unplugged } \\
\text { activity? }\end{array}$ \\
\hline 7 & Assistance & $\begin{array}{l}\text { Do learners have chance } \\
\text { for assistance from } \\
\text { teacher or friends? }\end{array}$ \\
\hline 8 & Communication & $\begin{array}{c}\text { Do learners have chance } \\
\text { to communicate each } \\
\text { other during unplugged } \\
\text { activity? }\end{array}$ \\
\hline 9 & Expandability & $\begin{array}{c}\text { Can learners expand the } \\
\text { unplugged activity with } \\
\text { more member? }\end{array}$ \\
\hline 10 & Applicability & $\begin{array}{l}\text { Can learners apply the } \\
\text { unplugged activity for } \\
\text { other similar activity? }\end{array}$ \\
\hline
\end{tabular}

\section{Conclusions and Further Research Issues}

Currently informatics education becomes popular in the forms of software education and ICT education, etc. Informatics education is important in raising human resource in artificial intelligence areas [6,7]. Informatics education also becomes mandatory education in primary and secondary schools in many countries.

Unplugged activity becomes popular in ICT education and software education since it does not require any special equipment including computer. It means that unplugged activity can be done any place any time. The main purpose of unplugged activity is to let learners' study computer science theory or 
principles with play activity.

In order for unplugged activity to be successful, the correct and general evaluation metrics for learners are necessary. It is very important to check how learners understand the overall principle or theory. However, in the literature, there is little research work on evaluation metrics for learners. In this paper, evaluation metrics are developed. The metrics are developed in accordance with design principles of unplugged activity and the general education purpose of ICT education.

The further research issues are as follows. First, it is necessary to refine the proposed evaluation metrics further. That is, more detailed metrics are necessary depending on various unplugged activities. Second, it is also necessary to test the validity of the proposed metrics. For this purpose, the extensive survey work and analysis work are essential.

\section{Conflict of Interest}

The authors declare no conflict of interest.

\section{References}

[1] W. C. Jun," A Study on Development of Evaluation Standards for Unplugged Activity" in 2018 International Conference on Information and Communication Technology Convergence, Jeju Island, Korea, 2018. http://10.1109/ICTC.2018.8539505

[2] J. R. Kim, "A Study on Systematic Review of Unplugged Activity" Journal of the Korean Society of Information Education, 22(1), 103-111, 2018. http://dx.doi.org/10.14352/jkaie.2018.22.1.103

[3] Y. H. Bae, C. S. Na, "Effectiveness of Unplugged Activity in Korean Education: A Meta-Analysis" The Journal of Educational Information and Media, 25(1), 121-150, 2019. http://dx.doi.org/10.15833/KAFEIAM.25.1.121

[4] W. K. Lee and J. M. Kim, "Research Report on Unplugged Activity", Research Report, The Korean Society of Computer Education, 2015.

[5] Y. J, Jang, D. H. Kim, H. S. Kim, W. K. Lee, H. C. Kim, "Development of Unplugged Activity and its Evaluation of Usability for Information Security Education" The Journal of Korean Association of Computer Education, 14(1), 55-67, 2011.

[6] C. Gokul, P. Sakthivel and P. R. Karthikeyan, Minimization of Test Time in System-on-Chip using Artificial Intelligence based Test Scheduling Techniques, Neural Computing \& Applications, 2019. https://doi.org/10.1007/s00521-019-04039-6.

[7] C. Gokul, P. Sakthivel and P. R. Karthikeyan, Test scheduling for system on chip using modified firefly and modified ABC algorithms, SN Applied Sciences. 1(9), 1079, 2019.

https://doi.org/10.1007/s42452-019-1116-x 